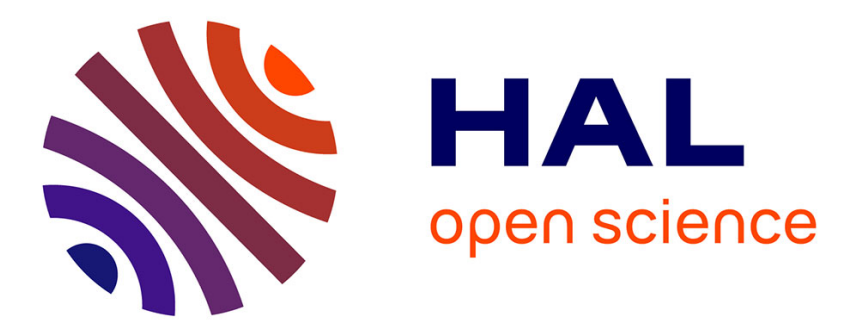

\title{
The importance of the surroundings: are bird communities of riparian galleries influenced by agroforestry matrices in SW Iberian Peninsula?
}

Pedro Pereira, Carlos Godinho, Marisa Gomes, João Eduardo Rabaça

\section{- To cite this version:}

Pedro Pereira, Carlos Godinho, Marisa Gomes, João Eduardo Rabaça. The importance of the surroundings: are bird communities of riparian galleries influenced by agroforestry matrices in SW Iberian Peninsula?. Annals of Forest Science, 2014, 71 (1), pp.33 - 41. 10.1007/s13595-012-0228-x . hal01098378

\section{HAL Id: hal-01098378 \\ https://hal.science/hal-01098378}

Submitted on 24 Dec 2014

HAL is a multi-disciplinary open access archive for the deposit and dissemination of scientific research documents, whether they are published or not. The documents may come from teaching and research institutions in France or abroad, or from public or private research centers.
L'archive ouverte pluridisciplinaire $\mathbf{H A L}$, est destinée au dépôt et à la diffusion de documents scientifiques de niveau recherche, publiés ou non, émanant des établissements d'enseignement et de recherche français ou étrangers, des laboratoires publics ou privés. 


\title{
The importance of the surroundings: are bird communities of riparian galleries influenced by agroforestry matrices in SW Iberian Peninsula?
}

\author{
Pedro Pereira • Carlos Godinho • Marisa Gomes • \\ João Eduardo Rabaça
}

Received: 20 January 2012 / Accepted: 16 July 2012 /Published online: 14 August 2012

(C) INRA / Springer-Verlag France 2012

\begin{abstract}
- Context The remaining riparian stretches are often the unique suitable habitats for forest breeding birds in Mediterranean landscapes undergoing long-term changes. Understanding the interactions between riparian zones and their surroundings is critical to establish successful management actions.

- Aims We assessed the influence of surrounding matrix on riparian bird communities and the use of riparian galleries as surrogate habitats for the forest passerine communities of southwestern Iberia.

- Methods We used point counts in three simultaneous sampling stations, one in the riparian gallery and two in the adjacent matrix. Three matrix types were selected with a decreasing tree density gradient: dense montado, sparse
\end{abstract}

\footnotetext{
Handling Editor: Paulo Sá-Sousa

Contribution of the co-authors Pedro Pereira conducted field work, data analysis, and manuscript writing. Carlos Godinho designed the experiment, conducted field work, and manuscript reviewing. Marisa Gomes conducted field work and manuscript reviewing. João Eduardo Rabaça conceived and designed the experiment, coordinated the research project, and participated in writing.
}

Electronic supplementary material The online version of this article (doi:10.1007/s13595-012-0228-x) contains supplementary material, which is available to authorized users.

P. Pereira $\cdot$ C. Godinho $\cdot$ M. Gomes · J. E. Rabaça

LabOr-Laboratório de Ornitologia, Departamento de Biologia,

ICAAM - Instituto de Ciências Agrárias e Ambientais

Mediterrânicas, Universidade de Évora,

Pólo da Mitra,

7002-544 Évora, Portugal

P. Pereira $(\square)$

LabOr-Laboratory of Ornithology, Department of Biology,

ICAAM - Institute of Mediterranean Agrarian and Environmental

Sciences, University of Évora,

7002-544 Évora, Portugal

e-mail: ppereira@uevora.pt montado, and open agricultural areas. Data were analysed with redundancy analysis and differences in species' occurrences were tested with one-way ANOVA.

- Results In riparian galleries, we found bird species belong to three ecological guilds: riparian, woodland, and edge guilds. The richness of bird guilds and the occurrence of some species depended on the surrounding matrix type. Riparian bird richness was constant in all surrounding matrices, woodland bird guild was richer in galleries embedded in dense montados, and edge guild in riparian galleries surrounded by sparse montados. Five among 19 assessed species were influenced by matrix type, within particular a few strictly riparian species. Species richness increased close to riparian galleries, due to the increase in habitat heterogeneity and resource availability for birds in densely vegetated riversides. However, the occurrence of some bird species differed according to the type of surrounding matrix.

- Conclusion The matrix type explained most of the variance in riparian bird assemblages. Some woodland birds have used riparian galleries as surrogate habitat. Our study suggests that land use in the surrounding matrices must be taking into account for the management and rehabilitation of watercourses and bird conservation actions.

Keywords Riparian galleries · Breeding bird assemblages · Agroforestry gradient $\cdot$ Montado

\section{Introduction}

Mediterranean landscapes have changed over time due to intensive land use for centuries, resulting in highly fragmented woodlands and reduced riparian galleries (e.g., Covas and Blondel 1998; Blondel and Aronson 1999; Larsen et al. 2010). In central-southern areas of the Iberian Peninsula, this long-term process of human interference in 
dense and continuous woodlands of evergreen oaks (mainly holm oak Quercus rotundifolia and/or cork oak Quercus suber) shaped the Portuguese montados and Spanish dehesas. Currently, these habitats are extensive agro-silvopastoral systems with reduced or eliminated shrubby layer in order to promote cereal crops and/or livestock grazing. The result is a heterogeneous matrix of different tree densities composed by a farmland and woodland mosaic crossed by natural corridors like riparian galleries and natural hedgerows. The process of forest clearing (past and present) in the low-density montados can modify the landscape structure and eventually promote edge effects, as observed in other fragmented forests (Murcia 1995). However, these parkland forested areas support a higher alpha and beta diversity of bird communities compared with other European forests, mostly due to a high abundance of farmland birds (e.g., Blondel and Aronson 1999; Díaz et al. 1997; Tellería 2001). Several authors have documented that composition of bird communities are determined not only by the regional pool of species, but mainly by landscape and patch features like the matrix type, patch width, size and shape, habitat configuration, floristic and physiognomic vegetation structure (e.g., Davis 2004; Gil-Tena et al. 2007). Forest features like tree and shrub densities are within the most important influences for bird assemblages in montados (Godinho and Rabaça 2011; Rabaça 1990). Furthermore, applying an ecological guild approach based on functional traits of habitat use often facilitates the understanding of birds' response to habitat and landscape features (Bryce et al. 2002; Bub et al. 2004; Mayer and Cameron 2003; Sullivan et al. 2007).

In river corridors, the structure of a well-developed riparian gallery can be comparable to woodland with shrubs in the understory, creating a dense vegetation cover with particular shade and wet conditions (e.g., Tubelis et al. 2004). Birds are often used as indicators of environmental changes in riparian systems, since birds have a high ability to use corridors, move among habitat patches, and react fast to ecological disturbances (e.g., Bryce et al. 2002; Larsen et al. 2010; Mayer and Cameron 2003; Sullivan et al. 2007). Nevertheless, studies on ecological relations among breeding birds, landscape elements, and riparian galleries are scarce from a community perspective (e.g., Bub et al. 2004; Strong and Bock 1990; Woinarski et al. 2000), especially in the Mediterranean Region (see Godinho et al. 2010; Larsen et al. 2010).

Our study aims to evaluate (1) if surrounding agroforestry matrices with different tree densities influence the composition of breeding bird communities associated with riparian galleries, and (2) if riparian galleries can be a surrogate habitat for forest breeding birds in SW Iberian Peninsula. Knowledge about the interactions between riparian ecosystems and their surroundings is critical to establish successful management actions in agroforestry systems (see
Martin et al. 2006), especially considering the relevance of river corridors in landscape planning and regional biodiversity maintenance (Bub et al. 2004; Deschênes et al. 2003; Naiman et al. 1993).

\section{Material and methods}

\subsection{Study area}

Fieldwork was conducted in Central Alentejo in the municipalities of Évora and Montemor-o-Novo $\left(7^{\circ} 40^{\prime}-8^{\circ} 16^{\prime} \mathrm{W}\right.$ and $38^{\circ} 27^{\prime}-38^{\circ} 41^{\prime} \mathrm{N}$; see figure in online Appendix 1 available at www.afs-journal.org). The area is characterized by smooth plains with an average altitude around $250 \mathrm{~m}$ (the highest elevation in the Monfurado Mountain, $420 \mathrm{~m}$ ). The climate is Mediterranean with hot and dry summers and moderate rainy winters. Average annual temperature is $12.5^{\circ} \mathrm{C}$ (from $9{ }^{\circ} \mathrm{C}$ in January to $25^{\circ} \mathrm{C}$ in July) and annual rainfall ranges from 600 to $1,000 \mathrm{~mm}$ (SNIRH 2007). Woody vegetation is dominated by cork and holm oaks in the tree layer, olive tree Olea europaea var. sylvestris, kermes oak Quercus coccifera and hawthorn Crataegus monogyna in intermediate layers, and gorses Ulex spp. and rock roses Cistus spp. in shrub layer. Common land uses are montados, cereal fields and fallows, creating a landscape gradient from decreasing forestry use to increasing agropastoral use. Stands with a higher density and diversity of woody vegetation are located in the western part; a gently undulating landscape with scattered oaks and crop cultures in the north and east; and a vast plain with cereal crops, pastures and fallows, and nearly no trees in the south. Cattle dominate the livestock, but sheep and pigs are also raised. Selected rivers are tributaries of the three major basins of central and south Portugal: the Tagus River in the northern part of the area, the Guadiana River in the southeastern part, and the Sado River in southwest. Surveyed stretches are characterized by soft slopes and a well-developed and continuous riparian gallery with deciduous trees like ash Fraxinus angustifolia, alder Alnus glutinosa, willows Salix alba, Salix atrocinerea, Salix salvifolia, and poplar Populus nigra. The riparian understory is dominated by bramble Rubus ulmifolius.

\subsection{Site selection and sampling procedures}

We selected study sites according to the following criteria: (1) stretches with continuous riparian vegetation (no less than $100 \mathrm{~m}$ length) in (2) small-sized streams with a band of riparian vegetation in both riversides, and (3) a uniform habitat typology in the surrounding matrix on both sides of the channel. We selected permanent small-sized streams (although in winter, it may present torrential flow) with a 
narrow riparian zone (c.15 m including the channel) because they are the dominant watercourses in the rural landscape of SW Iberia. Three types of matrix were chosen based on a forested gradient: dense montados (DM, with tree density $>40$ trees/ha), sparse montados (SM, tree density between 5 and 40 trees/ha), and open agricultural areas (OA, $<5$ trees/ ha; Fig. 1).

In order to detect areas that fitted our criteria, we used ArcGis 9.1 (ESRI 2004). Subsequently, potential areas were checked in the field and sampling sites established according to their easier access. We selected nine sampling sites in each agroforestry matrix type (totalizing 27 sampling sites) located at least $500 \mathrm{~m}$ apart from each other. In each sampling site, three 10-min point counts (sampling stations) with a $50 \mathrm{~m}$ radius limited distance (e.g., Bibby et al. 2005) were conducted exactly at the same time by three observers with similar aural and visual detection skills. Censuses started simultaneously after all the observers arrived to their assigned stations. In each sampling site, stations were located on the same riverside along a perpendicular line to the channel. The first station (s1) was close to the channel and the following stations were located in the matrix: the second (s2) $125 \mathrm{~m}$ from s1 and the third (s3) was located $125 \mathrm{~m}$ from s2 (Fig. 1). s2 and s3 were used in order to verify the homogeneity of bird community within matrix. This procedure provided us with a simultaneous snapshot of the birds present in each sampled area, and a better understanding of the birds' use of two different landscape elements: riparian galleries and matrices. Bias due to differences in the observers' bird detection was controlled through previous training in distance estimation. However, in spite of our heavy design, we could not preclude that matrix types could have affected differently the conspicuousness of the observer, which is expected to increase from DM to OA. As a result, we could not exclude the possibility of a subtle reduction in birds' detections in open areas. In order to increase the probability of detection of a given species, bird surveys were carried out twice during the breeding season of
2007 (totalizing 162 point counts). The first survey was conducted in late April and the second in the end of May. Surveys were conducted between 6.00 and 11.00 am and adverse weather conditions such as moderate rain or strong winds were avoided.

Bird species were grouped into three ecological guilds according to their functional use of ecological space (riparian, woodland and edge guilds; Table 1) based on species occurrence. Guild names follow a woodland perspective: riparian guild is composed by bird species dependent on riparian forests, woodland guild species includes bird species dependent on matrix forests and edge guild species do not have any forest dependence, being mostly ground nesters. Species richness and the frequency of bird occurrence were assessed for the riparian gallery (s1 stations) as well as for the surroundings (s2 and s3 stations). We excluded from our initial bird dataset (1) species with a wider spatial use of the census area, i.e., similar or larger than a common blackbird Turdus merula, insectivorous aerial flyers like swifts Apus spp., swallows Hirundo spp., Riparia riparia, and house martins Delichon urbicum; (2) birds detected only outside the census area; (3) unidentified birds species (belonging to these groups: sparrows Passer spp. and crested larks Galerida spp.) in order to avoid bias in analysis interpretation resulting from habitat differences of species within each species group; and (4) species recorded in less than $15 \%$ of all 81 sampling sites (e.g., kingfisher Alcedo atthis and grey wagtail Motacilla cinerea).

\subsection{Explanatory variables and data analysis}

For each bird species, we determined the frequency of occurrence in galleries (percentage of sampled galleries where a given species has occurred) and the proportion of total occurrence in galleries: percentage of occurrences in $\mathrm{s} 1$ in relation to all stations ( $\mathrm{s} 1, \mathrm{~s} 2$, and $\mathrm{s} 3$ ) where a given species has occurred. The first value is related with the
Fig. 1 Scheme showing an example of sampling site by each matrix type ( $D M$ dense montados, SM sparse montados, and $O A$ open areas) with the location of the three stations: $\mathrm{s} 1$ in the riparian gallery, s2 at $125 \mathrm{~m}$ from s1, and $\mathrm{s} 3$ at 125 from $\mathrm{s} 2$. The circles (with a $50 \mathrm{~m}$ radius) represent the census area by each station. Three simultaneous observers were located in the centre of each census area, recording all birds observed within the census area during $10 \mathrm{~min}$

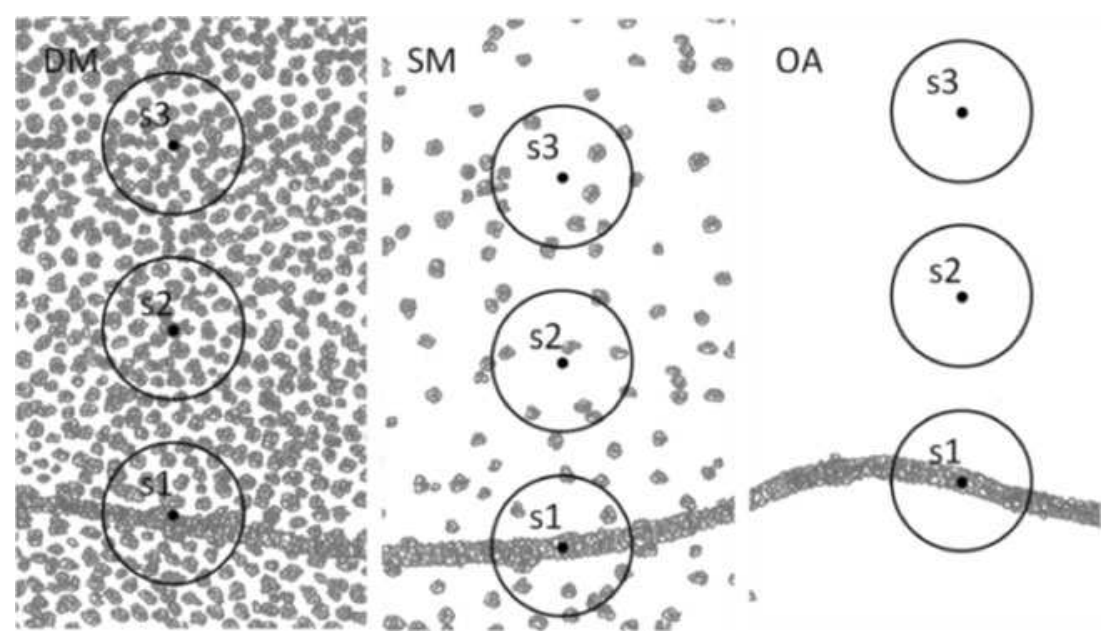


Table 1 Bird species included in the analysis, acronyms, English names, and ecological guilds ( $R G$ riparian guild, $E G$ edge guild, $W G$ woodland guild)

\begin{tabular}{|c|c|c|c|c|c|}
\hline Species & Acronym & English name & Guild & $\begin{array}{l}\text { Frequency of occurrence } \\
\text { in galleries }(\%)\end{array}$ & $\begin{array}{l}\text { Proportion of total } \\
\text { occurrence in galleries (\%) }\end{array}$ \\
\hline T. troglodytes $\mathrm{L}$. & Tro tro & Wren & RG & 81.5 & 100 \\
\hline L. megarhynchos Brehm & Lus meg & Nightingale & RG & 100 & 90.0 \\
\hline C. cetti Temminck & Cet cet & Cetti's warbler & RG & 51.9 & 100 \\
\hline Hippolais polyglottaVieillot & Hip pol & Melodious warbler & RG & 48.2 & 81.3 \\
\hline S. atricapilla $\mathrm{L}$. & Syl atr & Blackcap & RG & 85.2 & 85.2 \\
\hline S. serinus $\mathrm{L}$. & Ser ser & Serin & RG & 70.4 & 70.4 \\
\hline Carduelis chloris $\mathrm{L}$. & Car chl & Greenfinch & RG & 40.7 & 78.6 \\
\hline Carduelis carduelis L. & Car car & Goldfinch & RG & 70.4 & 67.9 \\
\hline Saxicola torquatus $\mathrm{L}$. & Sax tor & Stonechat & EG & 33.3 & 69.2 \\
\hline C. juncidis Raf. & Cis jun & Zitting cisticola & EG & 25.9 & 53.9 \\
\hline S. melanocephala Gmelin & Syl mel & Sardinian warbler & EG & 85.2 & 54.7 \\
\hline Lanius senator L. & Lan sen & Woodchat shrike & EG & 14.8 & 28.6 \\
\hline E. calandra $\mathrm{L}$. & Emb cal & Corn bunting & EG & 48.2 & 36.1 \\
\hline F. coelebs L. & Fri coe & Chaffinch & WG & 48.2 & 33.0 \\
\hline Aegithalos caudatus L. & Aeg cau & Long-tailed tit & WG & 40.7 & 50.0 \\
\hline C. caeruleus $\mathrm{L}$. & Cya cae & Blue tit & WG & 88.9 & 45.3 \\
\hline P. major L. & Par maj & Great tit & WG & 59.3 & 45.7 \\
\hline S. europaea L. & Sit eur & Nuthatch & WG & 7.41 & 7.69 \\
\hline C. brachydactyla Brehm & Cer bra & Short-toed treecreeper & WG & 44.4 & 29.3 \\
\hline
\end{tabular}

Frequency of occurrence for bird species in riparian galleries $(n=27)$ and proportion of occurrences in riparian galleries in relation to the number of stations with species occurrences

consistency of the species occurrence along riparian galleries, despite the surrounding matrix; the second highlights the relevance of galleries for each species in the study area.

We recorded two groups of environmental variables in each sampling station: vegetation structure (seven variables) and matrix type (three variables). We divided the matrix type according to tree cover in dense montados, sparse montados and open areas. Vegetation variables were grouped according to their ecological relevance and cover: large riparian trees (ash, alder, and poplar), willows, oak trees (holm and cork oaks), small woodland trees (olive tree, kermes oak, and hawthorn), woodland shrubs (gorses and rockroses), riparian shrubs (bramble), and herbaceous plants. We used redundancy analysis (RDA) as a descriptive and exploratory technique, using data multivariate analysis in Canoco for Windows 4.5 (ter Braak and Smilauer 2002). To evaluate the associations between environmental variables and bird assemblages, three different RDA were run, associating (1) agroforestry matrices (DM, SM, and OA), environmental variables and stations (s1, s2, and s3), (2) matrices and environmental variables, and (3) matrices, stations, and bird species. Variables were selected manually under an unrestricted model with Monte Carlo permutation tests ( 999 permutations).

We tested differences in the occurrences of bird guilds were tested using three separate one-way ANOVA (e.g.,
Bub et al. 2004; Deschênes et al. 2003; Strong and Bock 1990), using SPSS 16.0 for Windows (SPSS 2007). With all the 81 stations, we performed analysis using station and matrix type as independent variables. For all guilds, we tested the existence of differences in their richness in matrix stations (s2 and s3). Subsequently, the influence of the agroforestry matrix on riparian bird communities was assessed for each guild (with matrix type as an independent variable), using species occurrences in s1 stations.

\section{Results}

In all, 19 bird species satisfied our criteria and were included in our bird dataset for subsequent analysis (Table 1). All these species were recorded in riparian galleries but richness values were different depending on the matrix type: 19, 18, and 17 species were detected in s1 stations surrounded respectively by dense montados, sparse montados, and open areas. The average species richness in s2 was significantly different within the studied matrices, as well for s3 (Table 2).

Matrix type, environmental variables, and stations represented $68.1 \%$ of total explained variance for our data (Table 3). Strong similarities among stations from the same matrix type were found (78.1\% of explained variance). 
Table 2 Independent one-way ANOVA for bird species richness in the three stations (s1, s2, s3; n=27) at three different matrix types: dense montados, sparse montados, and open areas

\begin{tabular}{|c|c|c|c|c|c|}
\hline Stations & Dense montados & Sparse montados & Open areas & $F$ & $p$ \\
\hline s1 & $10.9 \pm 3.63$ & $10.3 \pm 3.44$ & $10.1 \pm 3.37$ & 0.62 & 0.56 \\
\hline s2 & $6.67 \pm 2.22$ & $3.44 \pm 1.15$ & $2.11 \pm 0.70$ & 8.90 & 0.01 \\
\hline s3 & $5.67 \pm 1.89$ & $6.56 \pm 2.19$ & $1.11 \pm 0.37$ & 31.2 & $<0.01$ \\
\hline
\end{tabular}

Since similarity of riparian galleries among all sites and matrix homogeneity in each class was verified, testing species-environmental correlations and the influence of the matrix in a riparian bird community was justifiable.

The RDA ordination results along the first two axes are plotted in Fig. 2. Arrows represent the environmental variables included in the model that explain most of the variation in species distribution. The length of each arrow expresses the relative importance of the corresponding variable in the model. The arrow direction in relation to the axes shows how well the environmental variable is correlated with each axis. The environmental condition associated with the presence of each species is showed by the closeness of bird species scores to the arrows. Bird species were highly correlated with selected environmental variables (explained variance $36.7 \%$ ). Species from the same guild are closely positioned in the RDA biplot and show a close relation with stations and matrices: riparian guild species were strictly associated with the riparian gallery (s1), woodland guild species dominated in dense montados, and edge guild species were associated with biplot centre and with open areas. The richness in riparian and woodland guilds increased from open areas to dense montados $(F=4.36, p<$ 0.05 and $F=35.3, p<0.05$, respectively), whereas the edge guild species richness was higher in sparse montados and lower in dense montados $(F=3.73, p<0.05)$.

In riparian galleries, the frequency of occurrence ranged from $7.41 \%$ for nuthatch Sitta europaea to $100 \%$ for nightingale Luscinia megarhynchos (Table 1). When we look to the proportion of the species occurrence in riparian galleries in relation to the total of the three stations (s1, s2, and s3), we found that wren Troglodytes troglodytes and Cetti's warbler Cettia cetti occurred strictly in galleries (proportion of total occurrence in galleries $=100 \%$ ), whereas nuthatch occurred mostly at matrices (only $7.69 \%$ in galleries) (Table 1). Some species were detected in all s1 stations of a given matrix surrounding and were more frequent in s1 than in the surroundings (Table 4): blue tit Cyanistes caeruleus, blackcap Sylvia atricapilla, and wren in dense montados, serin Serinus serinus in sparse montados, and Sardinian warbler Sylvia melanocephala in open areas.

In s1, when we compared the richness of each guild among each matrix type, differences were obtained for woodland and edge species. Accordingly, species richness of the riparian guild was constant in all types of matrix $(F=$ $0.155, p=0.860$ ), woodland guild richness was higher in galleries embedded in dense montados $(F=11.9, p<0.01)$ and edge guild richness was higher in riparian galleries surrounded by sparse montados $(F=11.2, p<0.01)$. Five species from the three guilds showed significant differences $(p \leq 0.05)$ in their frequencies in riparian galleries depending on the matrix type (Table 4). Cetti's warbler and serin (riparian guild species) occurred mainly in galleries surrounded respectively by open areas and montados (sparse or dense). Species from the edge guild like stonechat Saxicola torquatus and corn bunting Emberiza calandra, in galleries bordered respectively by sparse montados and

Table 3 Canonical eigenvalues, species variance, species-environmental correlations, and total explained variance for the first two axes of the redundancy analysis

\begin{tabular}{|c|c|c|c|c|}
\hline & & Axis I & Axis II & Total variance explained (\%) \\
\hline \multirow[t]{3}{*}{ Matrices/environmental variables/stations } & Canonical eigenvalues & 0.245 & 0.215 & \multirow{3}{*}{68.1} \\
\hline & Cumulative variance of species data $(\%)$ & 24.5 & 46.0 & \\
\hline & Species-environmental correlations & 0.989 & 0.927 & \\
\hline \multirow[t]{3}{*}{ Matrices/environmental variables } & Canonical eigenvalues & 0.430 & 0.351 & \multirow[t]{3}{*}{78.1} \\
\hline & Cumulative variance of species data $(\%)$ & 43.0 & 78.1 & \\
\hline & Species-environmental correlations & 0.927 & 0.838 & \\
\hline \multirow[t]{3}{*}{ Matrix/stations/species } & Canonical eigenvalues & 0.236 & 0.103 & \multirow[t]{3}{*}{36.7} \\
\hline & Cumulative variance of species data $(\%)$ & 23.6 & 33.9 & \\
\hline & Species-environmental correlations & 0.942 & 0.804 & \\
\hline
\end{tabular}




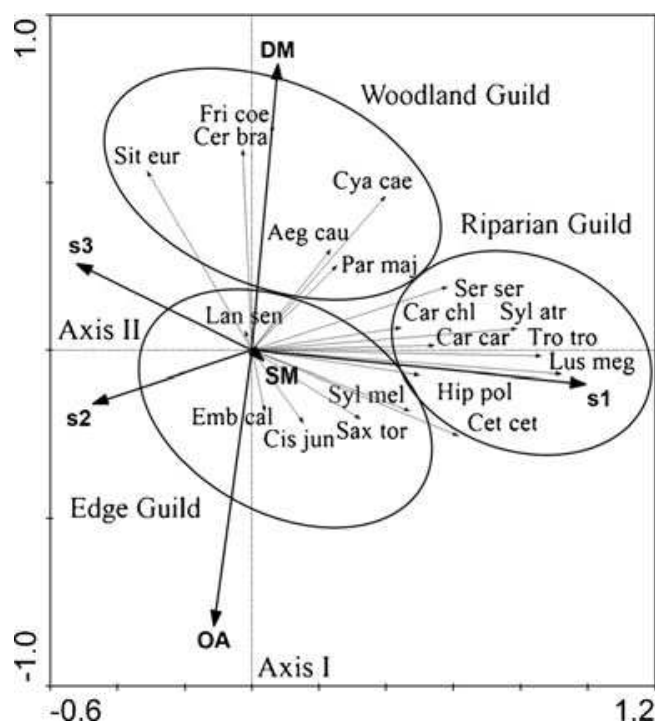

Fig. 2 Ordination biplot of the first two axes of the RDA for bird species, sampling stations (s1, s2, and s3) and matrix types (DM dense montados, SM sparse montados, $O A$ open areas). For species' acronyms, see Table 1 . The clusters grouped the three ecological guilds considered

open areas. Finally, the chaffinch Fringilla coelebs, a species from the woodland guild, occurred mainly in galleries surrounded by dense montados. These results suggest the

Table 4 Independent one-way ANOVA for bird species occurrence in the three stations (s1, s2, s3; $n=27)$, and for occurrences in riparian galleries (s1) embedded in three different matrix types $(n=9)$; for species' acronyms, see Table 1

\begin{tabular}{llllll}
\hline Acronym & \multicolumn{2}{l}{ Stations } & & & \multicolumn{2}{l}{ Galleries } \\
\cline { 2 - 3 } \cline { 5 - 6 } & $F$ & & & $F$ & $p$ \\
\hline Tro tro & 114 & $<0.01$ & & 1.75 & 0.195 \\
Lus meg & 223 & $<0.01$ & & - \\
Cet cet & 28.0 & $<0.01$ & & 4.55 & 0.0212 \\
Hip pol & 14.2 & $<0.01$ & & 0.13 & 0.876 \\
Syl atr & 60.8 & $<0.01$ & & 1.14 & 0.336 \\
Ser ser & 17.4 & $<0.01$ & & 7.00 & $<0.01$ \\
Car chl & 16.1 & $<0.01$ & & 0.160 & 0.853 \\
Car car & 9.39 & $<0.01$ & & 0.138 & 0.872 \\
Sax tor & 4.86 & 0.01 & 6.00 & 0.01 \\
Cis jun & 2.64 & 0.0779 & 0.174 & 0.841 \\
Syl mel & 2.68 & $<0.01$ & 2.15 & 0.138 \\
Lan sen & 2.48 & 0.0906 & 2.15 & 0.138 \\
Emb cal & 0.14 & 0.865 & 4.55 & 0.0212 \\
Fri coe & 2.43 & 0.0949 & 6.20 & $<0.01$ \\
Aeg cau & 4.49 & 0.0143 & 2.08 & 0.147 \\
Cya cae & 6.72 & $<0.01$ & 1.09 & 0.352 \\
Par maj & 2.20 & 0.118 & 2.08 & 0.147 \\
Sit eur & 6.34 & $<0.01$ & 2.29 & 0.123 \\
Cer bra & 1.23 & 0.299 & 1.85 & 0.180 \\
\hline
\end{tabular}

existence of a driving influence from the surrounding matrix on bird communities associated with the riparian gallery. Concerning the guild richness of the matrix stations, there were no differences detected for all guild richness between s2 and s3: riparian $(F=0.774, p=0.472)$, woodland $(F=$ $0.901, p=0.418)$, and edge species $(F=0.230, p=0.796)$.

\section{Discussion}

\subsection{Bird guilds and woodland traits}

Common and widespread European forest resident birds dominated the breeding bird communities in studied welldeveloped forests, such as riparian galleries and dense montados. This trait is similar to what has being detected in other riparian forests from Europe (e.g., Larsen et al. 2010; Godinho et al. 2010; Roché et al. 2010) and in European mature woodlands (Brotons et al. 2004; Gil-Tena et al. 2007; Rabaça 1990). Blondel and Farré (1988) described this observation as a tendency to convergence in the composition of bird communities associated with the last stages of different successional habitat gradients from several parts of Europe.

The selected stations in matrix (s2 and s3) were homogenous in terms of bird community composition. This is consistent with the uniformity of habitat typology in matrices, which was a criteria used for the selection of sampling sites. In the case of dense montados, it means continuity of suitable habitat available for woodland birds. We expect that in mature and continuous forests, woodland species might reach a higher reproductive performance than in disturbed or fragmented woodlands. Accordingly, in Mediterranean oak forests in Spain, Arriero et al. (2006) found that habitat maturity was an important factor determining the condition of blue tit females and therefore their breeding success. Since tree nesters (crown or cavity nesters) represent the major part of the woodland species, a higher cover of woody vegetation should increase their habitat suitability.

The higher fragmentation of woodland habitats observed in sparse montados can be responsible by the lower suitability of this matrix type for woodland birds. As discussed by Murcia (1995) in relation to other fragmented forest habitats, sparse montados are affected by edge effect through several reasons: intermediate habitat structure between DM and $\mathrm{OA}$; dominance of edge guild instead of woodland guild; eventual predation levels similar to those observed in open areas (e.g., Santos and Tellería 1992). Birds from the edge guild are the major part of bird communities in sparse montados and open areas. This result can indicate that a tree reduction below 40 trees/ha have high negative effects in the composition of woodland guild. Forest fragmentation through the reduction of vegetation complexity and 
microclimatic conditions in sparse montados can create edge effects reducing the habitat availability for woodland birds (see for instance Murcia 1995). However, in Iberian agroforestry landscapes, edges and farmlands can show lower predation rates on ground nests than forest interiors based on absence of specialist forest predators (Santos and Tellería 1992). Therefore, similar levels of low predation can contribute to increase bird community similarities between sparse montados and open areas. Moreover, in our study, the presence of isolated trees within the sampled area of three stations conducted in open areas could also contributed, even marginally, to increase such similarities. Notwithstanding, the species richness was lower in open areas. A higher human disturbance and lower complexity of vegetation in open areas result in a low availability of niches for birds (see for instance Atauri and de Lucio 2001). However, this fact can be also overinflated because (1) large species with wide territories were not included in the bird data set (e.g., species belonging to Phasionidae, Ciconiidae and Otidae) and (2) the conspicuousness of the observer eventually affected bird detections as previous mentioned.

With different degrees of human disturbance, all habitats used by edge bird guild are associated with forest fragmentation: open areas with scattered shrubs or trees, sparse montados and, more rarely, in glades within a dense montado matrix. However, within edge guild, we found birds with different tolerance to fragmentation. The fan-tailed warbler Cisticola juncidis and corn bunting are ground foragers and nesters well adapted to farming landscapes, although with different habitat preferences. The fan-tailed warbler, a bird of open areas with dense vegetation (e.g., cereal fields and fallows; see Delgado and Moreira 2000), was recorded mainly in open areas, while corn bunting was detected more often in sparse montados, similarly to what was found by Stoate et al. (2000) in extensive farming landscapes of Southern Portugal. This preference for sparse montados instead of open areas is also consistent with the habitat profile of corn buntings favouring the presence of wooded edges (e.g., Reino et al. 2009).

\subsection{The influence of the surroundings}

Generally, species richness increased close to the riparian gallery, due to greater habitat heterogeneity (see Berg 1997) and the availability of resources for birds provided by wellvegetated riversides (e.g., Bub et al. 2004). Several authors have documented that riparian bird assemblages are influenced by intrinsic gallery traits such as width, dominant tree species, and understory vegetation density (e.g., Bub et al. 2004; Godinho et al. 2010; Hodges and Krementz 1996; Strong and Bock 1990). The structural complexity of our riparian galleries is underlined by the most frequent bird species detected, associated with dense understory
(Sardinian warbler, nightingale, wren) and forested habitats in other European landscapes (e.g., blue tit, blackcap). The high diversity of food resources in riverside vegetation endorses the existence of different trophic categories in the riparian guild: exclusively insectivorous species (e.g., wren) or seedeater species (e.g., serin) and partly frugivorous birds (e.g., blackcap).

Climatic variables like rainfall precipitation (see Tellería and Santos 1993) are known to affect insectivorous birds, namely in matrix woodlands. Notwithstanding, the microclimatic conditions in riparian galleries can play an important role in the composition of bird community (e.g., Moore et al. 2005). Accordingly, these conditions can result not only from intrinsic gallery traits (e.g., vegetation typology) but also from extrinsic traits (e.g., surrounding matrix type). Our studied galleries showed a similar typology with well-developed and dense vegetation, creating higher moist conditions than surroundings matrix woodlands. These microclimatic conditions allow some typically woodland passerines of temperate Europe to occur in Mediterranean landscapes (e.g., wren and blackcap), since they are rare or absent from matrix woods (Godinho and Rabaça 2011; Tellería 2001). On the other hand, we admit that the occurrence of Cetti's warbler (a riparian species of Mediterranean origin) might be dependent on microclimatic conditions with an extrinsic source. Moore et al. (2005) discussed the existence of sharp differences in maximum temperatures if the surroundings are forests or open areas. The marked thermal variation between riparian galleries and open areas will influence ecological conditions for several organisms, namely ectothermic animals such as insects, whose levels of parasitism are lower in strong edge habitats (see for instance Murcia 1995; Roland et al. 1997). Therefore, the high source of food and the warm and dry conditions can eventually justify the high frequency of the Cetti's warbler in the riparian galleries embedded in open areas.

Some bird species occurred preferentially in galleries although they are not typically riparian species. The serin was included in the riparian guild, although it is usually considered a ubiquitous species. Ultimately, tallest trees in riparian galleries might have been selected as song perches rather than smaller trees in surroundings (authors' personal observation). Therefore, the low preference for the matrix drives the serin into the riparian gallery. This suggests a high attractiveness of the gallery for woodland species (e.g., great tit Parus major and short-toed treecreeper Certhia brachydactyla) which can use riparian galleries as a surrogate habitat, mainly due to the increase of agropastoral activities in the matrix, which in the end will lead to a treeless landscape. Moreover, riparian galleries are frequently the single forested patches in an open-area landscape, thus representing the only breeding and feeding site available to several bird species (e.g., Deschênes et al. 2003; Strong and Bock 1990). 
Our studied stretches were selected mainly in secondorder streams (in the sense of Strahler number). We are aware that this fact associated with sampling constrains (number of sampling sites and geographical location) preclude inferences at a broader scale. However, we believe that the agroforestry gradient used in this study and selected sampling sites provide a satisfactory picture of the rural landscapes from SW Iberian Peninsula, especially in areas with a similar geomorphology (smooth plains with scattered and soft elevations), which indeed are dominant in the region.

\subsection{Conclusions}

The agroforestry matrix types explained most of the variance in riparian breeding bird assemblages, which seemed to be more dependent on matrix traits than on the riparian gallery vegetation. We should underline that a well-structured gallery with dense and diverse woody vegetation on river edges is important to breeding bird assemblages, namely in areas dominated by forestdepleted landscapes such as extensive Mediterranean farming systems. In our study area, the occurrence of woodland or edge guild species in riparian galleries was consistent with their dominance in neighbourhood matrices. Some edge species can occur mostly near the edge, highlighting the importance of the mosaic structure of montados where patches of wooded areas, clearings and shrubs create a patchwork of habitats providing trophic and habitat conditions for birds of different ecological guilds. Similar to Martin et al. (2006), our study suggest that land use in the surroundings should be take into consideration in the management and rehabilitation of watercourses and in bird conservation actions. This should be relevant for the stakeholders involved with agroforestry ecosystems (landowners, land managers, decision makers) and to the society in highlighting the different values of riparian ecosystems (economic, social and biological; see Malanson 1993). Additionally, since every landowner should protect a riparian stretch in order to preserve biodiversity, fulfilling the EU legislation, the importance of watercourses protection is highlighted since stretches are the connecting element in the landscape.

Acknowledgments We acknowledge valuable discussion with Jean Roché and Bernard Frochot during a meeting in Montpellier, which helped setting up the ideas for this study. The authors are grateful to two anonymous referees for valuable comments and suggestions to an earlier version of this paper.

Funding This study was funded by INTERREG III C South-Project $n^{\circ}$ 3S0125I/RIPIDURABLE: Sustainable Management of Riparian Areas.

\section{References}

Arriero E, Sanz JJ, Romero-Pujante M (2006) Habitat structure in Mediterranean deciduous oak forests in relation to reproductive success in the Blue Tit Parus caeruleus. Bird Study 53:12-19

Atauri JA, de Lucio JV (2001) The role of landscape structure in species richness distribution of birds, amphibians, reptiles and lepidopterans in Mediterranean landscapes. Land Ecol 16:147159

Berg A (1997) Diversity and abundance of birds in relation to forest fragmentation, habitat quality and heterogeneity. Bird Study 44:355-366

Bibby CJ, Burgess ND, Hill DA, Mustoe SH (2005) Bird census techniques, 2nd edn. Elsevier, London

Blondel J, Aronson J (1999) Biology and wildlife of the Mediterranean Region. Cambridge University Press, Cambridge

Blondel J, Farré H (1988) The convergent trajectories of bird communities in European forests. Oecol 75:83-93

Brotons L, Wilfried T, Araújo MB, Hirzel AH (2004) Presenceabsence versus presence-only modelling methods for predicting bird habitat suitability. Ecogr 27:437-448

Bryce SA, Hughes RM, Kaufmann PR (2002) Development of a Bird Integrity Index: using bird assemblages as indicators of riparian condition. Environ Manag 30:294-310

Bub BR, Flaspohler DJ, Huckins DJ (2004) Riparian and upland breeding-bird assemblages along headwater streams in Michigan's Upper Peninsula. J Wildl Manag 68:383-392

Covas R, Blondel J (1998) Biogeography and history of Mediterranean bird fauna. Ibis 140:395-407

Davis SK (2004) Area sensitivity in grassland passerines: effects of patch size, patch shape, and vegetation structure on bird abundance and occurrence in southern Saskatchewan. Auk 121:1130 1145

Delgado A, Moreira F (2000) Bird assemblages of an Iberian cereal steppe. Agric Ecosyst Environ 78:65-76

Deschênes M, Bélanger L, Giroux JF (2003) Use of farmland riparian strips by declining and crop damaging birds. Agric Ecosyst Environ 95:567-577

Díaz M, Campos P, Pulido FJ (1997) The Spanish dehesas: a diversity in land-use and wildlife. In: Pain DJ, Pienkowski MW (eds) Farming and birds in Europe. Academic, Cambridge, pp 178-209

ESRI (2004) ArcGis. Version 9.1. Environmental Systems Research Institute, Inc, Redlands, CA

Gil-Tena A, Saura S, Brotons L (2007) Effects of forest composition and structure on bird species richness in a Mediterranean context: implications for forest ecosystem management. For Ecol Manag 242:470-476

Godinho C, Rabaça JE (2011) Birds like it Corky: the influence of habitat features and management of 'montados' in breeding bird communities. Agrofor Syst 82:183-195

Godinho C, Rabaça JE, Segurado P (2010) Breeding bird assemblages in riparian galleries of the Guadiana River basin (Portugal): the effect of spatial structure and habitat variables. Ecol Res 25:283-294

Hodges MF Jr, Krementz DG (1996) Neotropical migratory breeding bird communities in riparian forests of different widths along the Altamaha River, Georgia. Wilson Bull 108:496-506

SPSS Inc (2007) SPSS 16.0 for Windows. Chicago. IL

Larsen S, Sorace A, Mancini L (2010) Riparian bird communities as indicators of human impacts along Mediterranean streams. Environ Manag 45:261-273

Malanson GR (1993) Riparian landscapes. Cambridge University Press, Cambridge

Martin TG, McIntyre S, Catterall CP, Possingham HP (2006) Is landscape context important for riparian conservation? Biol Cons 127:201-214 
Mayer AL, Cameron GN (2003) Landscape characteristics, spatial extent, and breeding bird diversity in Ohio, USA. Div and Distrib 9:297-311

Moore RD, Spittlehouse DL, Story A (2005) Riparian microclimate and stream temperature response to forest harvesting: a review. Am Water Resour Assoc 41:813-883

Murcia C (1995) Edge effects in fragmented forests: implications for conservation. Trends Ecol Evol 10:58-62

Naiman RJ, Décamps H, Pollock M (1993) The role of riparian corridors in maintaining regional biodiversity. Ecol Appl 3:209212

Rabaça JE (1990) The influence of shrubby understory in breeding bird communities of Cork Oak (Quercus suber L.) woodlands in Portugal. Port Zool 1:1-6

Reino L, Beja P, Osborne PE, Morgado R, Fabiao AD, Rotenberry J (2009) Distance to edges, edge contrast and landscape fragmentation: interactions affecting farmland birds around forest plantations. Biol Conserv 142:824-838

Roché J, Faivre B, Frochot B (2010) Suivi temporel des oiseaux nicheurs en rivière (Programme STORI): évolution sur 16 années (1991-2006) des communautés de l'Allier. Alauda 78:253-268

Roland J, Taylor P, Cooke B (1997) Forest structure and the spatial pattern of parasitoid attack. In: Watt AD, Stork NE, Hunter MD (eds) Forests and Insects. Chapman \& Hall, London, pp 97-106

Santos T, Tellería JL (1992) Edge effects on nest predation in Mediterranean fragmented forests. Biol Cons 60:1-5
SNIRH (2007) Meteorologia. Sistema Nacional de Informação de Recursos Hídricos, Lisboa. http://snirh.pt. Accessed 20 February 2011

Stoate C, Borralho RJ, Araújo M (2000) Factors affecting corn bunting Miliaria calandra abundance in a Portuguese agricultural landscape. Agr Ecosyst Environ 77:219-226

Strong TR, Bock CE (1990) Bird species distribution in riparian habitats in Southeastern Arizona. Condor 96:866-885

Sullivan SMP, Watzin MC, Keeton WS (2007) A riverscape perspective on habitat associations among riverine bird assemblages in the Lake Champlain Basin, USA. Landsc Ecol 22:1169-1186

Tellería JL (2001) Passerine bird communities of Iberian dehesas: a review. Anim Biodivers Conserv 24:67-78

Tellería JL, Santos T (1993) Distributional patterns of insectivorous passerines in the Iberian forests: does abundance decrease near the border? J Biogeogr 20:235-240

ter Braak CJF, Smilauer P (2002) CANOCO reference manual and CanoDraw for Windows user's guide: software for canonical community ordination (version 4.5). Microcomputer Power, Ithaca

Tubelis DP, Lindenmayer DB, Cowling A (2004) Novel patch-matrix interactions: patch width influences matrix use by birds. Oikos 107:634-644

Woinarski JCZ, Brock C, Armstrong M, Hempel C, Cheal D, Brennan $\mathrm{K}$ (2000) Bird distribution in riparian vegetation in the extensive natural landscape of Australia's tropical savanna: a broad-scale survey and analysis of a distributional data base. J Biogeogr $27: 843-868$ 